\title{
The Effectiveness of Model Think Pair Share to Social Science Learning Outcomes of Grade III Students of Primary Schools in Unit Of Ahmad Yani District of Boja Kendal Regency
}

\author{
Khanifah Yuliastuti ${ }^{\square}$, Nuraeni Abbas \\ Primary School Teacher Education Department, Faculty of Education, Universitas Negeri Semarang \\ Corresponding email: khanifahyuli95@gmail.com
}

\begin{abstract}
The problem found in Elementary School Ahmad Yani cluster Kendal was the low learning achievement of IPS subject. This was caused by several aspects such as the less varied learning model, the inability of students to use their own knowledge, and lack of critical thinking in problem solving. Therefore, there is a need to provide innovative model to create more effective teaching and learning process. To answer such problem, this study used Quasi-Experimental research method with Nonequivalent Control Group Design. Through this design, the researchers involved all the third grade of Elementary School in Ahmad Yani Cluster Kendal as the population of this study. They were sampled by using cluster sampling. After the samples were obtained, the researchers decided experimental and control groups. They were as many as 28 students of SD 2 Campurejo involved as the experimental group, while 22 students of SD 2 Tampingan as the control group. In addition, the dependent variable of this study was Think Pair Share model, while the independent variable was IPS subject learning achievement with the topic of the history of currency. Their data were collected using observation, documentation and tests. Meanwhile, the hypotheses and effectiveness were examined by using t-test and gain test. The results of the study showed that Think Pair Share model was effective toward IPS subject learning achievement of the third grade students with the topic of the history of currency. Further, the posttest average score of experimental class was higher than control class. Also, the posttest mean of experimental group was 78.6 and the posttest mean of control group was 67.7. Moreover, the calculation of gain index showed that experimental class was on fair category with the score of 0.6180 , while the control class achieved the criteria as many as 0.4055. At last, this study suggests that TPS model is better to use in any subjects in order to create innovative teaching and learning.
\end{abstract}

Keywords: IPS subject, learning achievement, Think Pair Share model

\section{Introduction}

The learning process in primary schools refers to the curriculum of primary education. One of the compulsory subjects included in the curriculum of primary education is Social Science subject under Undang-Undang Nomor 20 Tahun 2003 Pasal 37 ayat 1 (Act of Republic of Indonesia:2003/37 article 1). It is explained further on Standard of Contents for Primary and Secondary Schools determined by National Board of Educational Standards (BSNP) among which explains about the background, the objectives, and the scopes of the Social Science subject. Social science studies a series of phenomena, facts, concepts, and generalizations related to social issues.

In the Social Science learning process in the primary school, its application is still not at its best as there are still some problems found. The problems found in primary school vary and are numberless. Social science is one of the difficult subjects as it comprises the lesson to memorize, thus, the students find understanding the lessons the teacher delivers difficult. The teacher plays important role in the learning success. As the varying learning methods and models are important in order to make the students attentive at the learning.

Think Pair Share (TPS) can be solution to the problems of Social science learning. Think Pair Share (TPS) is a method of cooperative learning that gives the students time to think and to respond to as well as to help one another. The cooperative learning, mainly Think Pair Share (TPS) is relatively simple as it does not take a long time both to manage the seats and to group the students. The learning makes the students learn to express their opinion and to appreciate their peers. (Aris, 2014:208)

A research was conducted by Nyoman Ayu Aryani, I Nyoman Jampel, I Kadek Suartama titled "Pengaruh Model Pembelajaran Think Pair Share (TPS) Terhadap Prestasi Belajar Pada Pembelajaran IPS Siswa Kelas V Sd Di Gugus III Kecamatan Seririt Kabupaten Buleleng Tahun Pelajaran 2013/2014" (The Impact of Think Pair Share (TPS) Method on Learning Achievement in the Social Science Learning of Grade V Students of the Primary Schools in Unit III of District of Seririt, Buleleng Regency during 2013/214 School Year). The study shows that application of TPS has impact on learning achievement. This was shown by the 
average score the students got after applying Think Pair Share (TPS), i.e. 36.45 which means good and after applying direct instruction, i.e. 29.51 which means poor and from t-test, i.e. $\mathrm{t}$ count $=8.464$, and $\mathrm{t}$-table $=1.671$ so $\mathrm{t}$-count $>\mathrm{t}-$ table. The score of t-test shows that Think Pair Share (TPS) method has impact on students Social Science learning achievement.

The study conducted by Purnomo dan Suprayitno (Vol. 1 No. 2/2013) titled "Peningkatan Kemampuan Berpikir Kritis Siswa dengan Penerapan Model Pembelajaran Kooperatif Tipe TPS (Think Pair Share) dalam Pembelajaran IPS di Sekolah Dasar" [The Improvement of Students' Critical Thinking Skill by Applying Cooperative Learning Mainly Think Pair Share (TPS) to the Social Science Learning in Primary School] shows that the teacher's activities along three cycles, i.e. at cycle I $(75.75 \%)$, in cycle II improved to $89.39 \%$, and in cycle III improved into $95.45 \%$. The students activeness in cycle I was $6.69 \%$, in cycle II improved into $80.3 \%$, and in cycle III improved into $93.93 \%$. The students learning outcome at cycle I was $67.56 \%$, at cycle II was $81.08 \%$ and in cycle III raised into $94.6 \%$. They could conclude that the application of cooperative learning mainly TPS could improve the students' critical thinking skill in Social Science learning of grade IV students SDN JerukI/469 Surabaya.

Another research was conducted by Lestary, Suripto, and Suhartono of Department of Primary Education, Faculty of Education and Teaching, Universitas Sebelas Maret titled "Penerapan Model Kooperatif Tipe Think Pair Share dalam Peningkatan Pembelajaran IPS pada Siswa Kelas V SDN 1 Purwogondo Tahun Ajaran 2013/2014" (The Application of Think Pair Share of Cooperative Learning for Improvement of Social Science Learning to Grade V Students of SDN 1 Purwogondo in 2013/2014 School Year). This study aims to improve Social Science learning of grade V students through application of Think Pair Share of cooperative learning. This study was collaborative classroom action research in three cycles, i.e. planning, implementation, observation, and reflection phases. Subject of the study was 30 grade V students SDN 1 Purwogondo comprising 17 males and 13 females. The study showed that the application of Think Pair Share of cooperative learning could improve the Social Science learning outcomes of grade V students of SDN 1 Purwogondo in 2013/2014 school year.

The problems in this investigation are (1) Can Social Science learning outcomes of grade III students of public primary schools of Ahmad Yani Unit in Kendal meet KKM after application of Think Pair Share dapat mencapai KKM? (2) Is the application of Think Pair Share more effective to improve Social Science learning outcomes of grade III students of public primary schools of Ahmad Yani Unit in Kendal ?

The study aims (1) To find if Social Science learning outcomes of grade III students of public primary schools of Ahmad Yani Unit in Kendal after applying Think Pair Share can meet KKM. (2) To find the effectiveness of Think Pair Share application to Social Science learning outcomes of grade III students of public primary schools of Ahmad Yani Unit in Kendal

\section{Research Methods}

The study was quasi-experimental research the population of which was grade III students of public primary schools of Ahmad Yani Unit in Kendal during 2016/2017 school year. The study used nonequivalent control group design (Sugiyono, 2015:114). The design engaged two classrooms, i.e. experimental classroom applying Think Pair Share and control classroom applying Snowball Throwing.

Population of the study was grade III students of public primary schools of Ahmad Yani Unit in Kendal. The sampling method used in the study was cluster sampling. Cluster sampling is the sampling plan in which the total population is divided into these groups (known as clusters) and a simple random sample of the groups is selected. The samples are determined after conducting normality and homogeneity test. Then, the clusters confirmed as normally distributed and homogeneous are randomly selected to determine which one is the experimental classroom, control classroom, and pilot classroom. The sampling picking determines three classroom that will be used, i.e. grade III of SD N 2 Campurejo as experimental classroom, grade III of SD N 2 Tampingan as control classroom and SD N 1 Tampingan as pilot classroom.

Variables of the research are: (1) independent variable, i.e. Think Pair Share; (2) dependent variable, i.e. grade III students Social Science learning outcomes. The data were collected through tests and non-tests, i.e. 
observation and documentation. Before the questions of the test as instrument was used, I had conducted test tool analysis, i.e. validity and reliability tests. The validity test was conducted using point biserial formula. Reliability test was conducted using K-R 20 formula.

Initial data analysis (pretest scores) used in the study comprises normality test, homogeneity test, and mean equivalence test. The precondition test used for final data analysis was normality and homogeneity tests for posttest scores. Then I conducted hypothesis test 1, i.e. learning mastery test using z-test. I picked 67 as KKM. Then I took hypothesis test 2, i.e. learning effectiveness test using t-test, then I made average improvement test using $\mathrm{N}$-gain.

\section{Results And Discussion}

\section{Initial Data Analysis}

Data analysis for normality test used Lilliefors test. The calculation using lilliefors test at level of significance 0.05 shows that value of significance of experimental classroom was 0.200 or more than 0.5 , thus, Ho was accepted which means that the pretest scores in the experimental classroom was normally distributed. The value of significance of the control classroom was 0.200, thus, Ho was accepted, which means that the pretest scores in control classroom was normally distributed. Data analysis for homogeneity test used F-test. The calculation using F-test at level of significance 0.05 shows that in the experimental and control classrooms, the value was 0.476 or more than 0.5 , thus $\mathrm{H}_{0}$ was accepted, which means that the pretest scores in experimental and control classrooms were homogeneous. Therefore, I can draw a conclusion that the initial data of pretest scores between experimental and control classrooms were homogeneous.

Based on the initial data analysis, I can make conclusion that the pretest scores of the two classrooms were distributed normally, homogeneous, and in the condition that the students had equivalent initial mastery.

\section{Final Data Analysis}

Normality test for the final data (posttest) of experimental and control classrooms used Lilliefors test at level of significance 0.05 . The value of significance found in experimental classroom was 0.111 and in control classroom was 0.68. Level of significance of the two data was more than 0.05 , thus, the final data was distributed normally.

Homogeneity test for final data (posttest)of experimental and control classrooms used Lilliefors test at level of significance 0.05. The value of significance found in experimental classroom control classroom was 0.72 or it exceeded the determined level of significance, i.e. 0.05 . Therefore, I can draw a conclusion that the final data of posttest scores between experimental and control classroom was homogeneous.

The average Pretest-Posttest improvement test used $\mathrm{N}$-Gain to calculate the improvement rate of pretest and posttest results between experimental and control classrooms that were treated differently. The average pretest and posttest scores are presented below:

Table 1 Average pretest and posttest scores of experimental and control classrooms

\begin{tabular}{|c|c|c|c|}
\hline \multirow[b]{2}{*}{ No } & \multirow[b]{2}{*}{$\begin{array}{c}\text { Classroom } \\
\text { Type }\end{array}$} & \multicolumn{2}{|c|}{ Mean } \\
\hline & & $\begin{array}{c}\text { Pret } \\
\text { est }\end{array}$ & $\begin{array}{c}\text { Postt } \\
\text { est }\end{array}$ \\
\hline 1 & $\begin{array}{c}\text { Experimenta } \\
1 \text { Classroom } \\
\text { Control }\end{array}$ & 44.6 & 78.6 \\
\hline 2 & Classroom & 45.5 & 67.6 \\
\hline
\end{tabular}

The average improvement test in experimental and control classrooms are presented below:

Table 2 Test of Average Improvement (N-Gain)

\begin{tabular}{ccccc}
\hline & \multicolumn{4}{c}{ Mean } \\
& Classroom & Pre & Post & \\
No & Type & test & test & $(\mathrm{g})$ \\
\hline & Experimental & 44. & & 0.613718 \\
1 & Classroom & 6 & 78.6 & 412 \\
& Control & 45. & & 0.405504 \\
2 & Classroom & 5 & 67.6 & 587 \\
\hline
\end{tabular}

I can draw a conclusion that the improvement of learning outcomes in experimental classroom applying Think Pair Share was higher than the one in control classroom applying Snowball Throwing.

Think Pair Share is more effective to improve the learning outcomes of cognitive aspect for Social Science subject at grade III than Snowball Throwing applied to control classroom. It was because the cooperative learning, Snowball Throwing applied to control classroom focused on the group usage and did not give the students any chances to actively cooperate in a group to solve the given problem. Think Pair 
Share could help the students by solving problem in the form of questions by discussing it with their deskmates. Therefore, they could find the right answers. It was shown by pretest and posttest scores. The average posttest score of experimental classroom was higher than that of control one.

The learning was conducted for lesson two in SDN 2 Campurejo as experimental classroom using Think Pair Share. The time allocated for the learning was 2 × 35 minutes (70 minutes) for each lesson. The learning activities were introductory, core, and closing activities.

Lesson two, three, and four were similar to the lesson one. Their difference was only the lesson materials for $2 \times 35$ minutes (70 minutes) for each lesson. At lesson two, they learn about the characteristics of money and its value; at lesson three, they learn about the benefit of money for us; and at lesson four, they learn about money management. The learning process in the experimental classroom, in order to help the students solve the problem, was conducted in pairs, thus, the students could share their opinion to their group mates.

In control classroom, grade III students of SDN 2 Tampingan, during the learning process, applied Snowball Throwing. As usual, the learning activities were introductory, core, and closing activities.

Lesson two, three, and four were similar to the lesson one. Their difference was only the lesson materials. At lesson two, they learn about the characteristics of money and its value; at lesson three, they learn about the benefit of money for us; and at lesson four, they learn about money management. The learning process in the experimental classroom, in order to help the students solve the problem, was doing exercises.

The study is relevant to the one conducted by Jasdilla, et.al.(2017) that aimed to improve Social Science learning outcomes by applying Think Pair Share to grade IV students. The research procedure comprised planning, implementation, observation, and reflection. The data analysis used in the study was thematic analysis. Data validity in the study showed the improvement of Social Science learning outcome from $76.75 \%$ into $89.67 \%$ (excellent). It showed that Think Pair Share could improve grade IV students Social Science learning outcomes.

The study is also relevant to the one conducted by Nyoman Ayu Aryani, et.al. (2014) that showed that average improvement was found in both experimental and control classrooms. The average improvement of experimental classroom was 36.45 while that of control classroom was 29.51. Based on t-test, I found that t-count was $8.464>$ t-table (1.617). It showed that Think Pair Share had impact on the students learning outcomes.

\section{Conclusion}

The conclusion of the study are: (1) The experimental classroom applying Think Pair Share can be confirmed as collectively meet the $\mathrm{KKM}$ as the number of the students who got more than 75 for their posttest was $75 \%$ or more. (2) Think Pair Share method is more effective than the learning method applied to the control classroom to improve the Mathematics learning outcomes of grade III students of public primary schools in Ahmad Yani Unit, Kendal.

\section{References}

Achmad Rifa'i. 2012. Psikologi Pendidikan. Semarang: Pusat Pengembangan MKU/MKDK-LP3 Universitas Negeri Semarang

Arikunto Suharsim,i. 2010. Prosedur Penelitian. Jakarta: Rinera Cipta

Djamarah Ayaiful Bahri, Zain Aswan. 2013. Strategi Belajar Mengajar. Jakarta: Rinera Cipta

Hamalik Oemar. 2009. Proses Belajar Mengajar. Jakarta: PT Bumi Aksara

Lestary, dkk. 2014. Penerapan Model Kooperatif Tipe Think Pair Share dalam Peningkatan Pembelajaran IPS pada Siswa Kelas V SDN 1 Purwogondo Tahun Ajaran 2013/2014.

Nyoman Ayu Aryani, dkk. 2014. Pengaruh Model Pembelajaran Think Pair Share (TPS) Terhadap Prestasi Belajar Pada Pembelajaran IPS Siswa Kelas V Sd Di Gugus III Kecamatan Seririt Kabupaten Buleleng Tahun Pelajaran 2013/2014. Vol.2 No.1

Poerwanti, Endang, dkk. 2008. Asesmen Pembelajaran di SD. Jakarta: Departemen Pendidikan Nasional

Purnomo, Suprayitno. 2013. Peningkatan Kemampuan Berpikir Kritis Siswa dengan Penerapan Model Pembelajaran Kooperatif Tipe TPS ( Think Pair Share ) dalam Pembelajaran IPS di Sekolah Dasar. Vol. 1 No. 2 
Shoimin Aris, 2014. 68 Model Pembelajaran Inovatif dalam Kurikulum 2013. Yogyakarta: Ar-Ruzz Media

Slamet., 2013. Belajar dan Faktor-Faktor yang Mempengaruhinya. Jakarta: Rinera Cipta

Sugiyono. 2010. Statistika untuk Penelitian. Bandung: Alfabeta
Susanto. Achmad. 2013. Teori Belajar dan Pembelajaran di Sekolah Dasar. Jakarta: Prenadamedia Group

Trianto. 2014. Model Pembelajaran Terpadu. Jakarta: PT Bumi Aksara. 